\title{
Microstructural relation of macerals with mineral matter in coals from Ib valley and Umaria, Son-Mahanadi basin, India
}

\author{
Vivek Mishra $^{1} \cdot$ K. N. Singh ${ }^{2}$
}

Received: 15 January 2017/Revised: 11 April 2017/ Accepted: 4 May 2017/Published online: 16 May 2017

(C) The Author(s) 2017. This article is an open access publication

\begin{abstract}
Coal petrology provides significant inputs for the industrial utilisation of coal and for broad understanding the coal formation and diagenesis. The present paper entails the results of the investigations carried out on the selected coal samples, from Ib valley and Umaria coalfield, using scanning electron microscope (SEM) and X-ray diffraction (XRD) to study the surface microstructures and minerals present in them and the relationship of the finely dispersed mineral matter with the organic constituents. This would further help in evaluating the distribution and chemical character of the mineral matter occurring within the maceral types. Ib valley and Umaria coals are typical Indian (Lower Gondwana) non-coking coals and only scanty data is available on SEM study of these coals. Under SEM examination, it manifests that, the mineral matters of these coal occur as deep intergrowth, massive impregnation, superficial mounting, filling and depletion of micropores, mechanical cavity filling and fusinitic cavity filling.
\end{abstract}

Keywords Coal $\cdot$ SEM $\cdot$ XRD $\cdot$ Umaria coal $\cdot$ Ib valley coal $\cdot$ India

\section{Introduction}

Coal is an organic biological rock (Xie 2015), formed from dead plant remains that accumulated to a certain thickness in a basin and was subsequently covered by the sediments through physical, chemical, and biological processes in an appropriate geological environment over a long geological time. Coal, therefore, contains organic matter and mineral matters in variable quantities. About $95 \mathrm{wt} \%$ of mineral matters consist usually of shale, kaolin, sulphide and chlorite (Shirazi et al. 1994; Saikia 2009). The heterogeneity in coal has the prime importance in the structural characterisation of coal (Thomas 1986). Its heterogeneity at the macroscopic level is reflected as banded structures as

Vivek Mishra

vmishranml@gmail.com

1 CSIR - National Metallurgical Laboratory, Jamshedpur 831007, India

2 School of Studies in Earth Science, Vikram University, Ujjain 456010, India shown in Fig. 1; most of the plant materials, except in very low rank coal, appears almost structureless in final product, coal (Seyler 1928; Kroeger 1964; Winston 1988, 1989; Pierce et al. 1991; Stanton and Moore 1991; Moore and Ferm 1992; Shearer 1992). At times, there is difficulty in distinguishing the inorganically-bound minerals and elements from the organically-bound ash-forming elements and minerals (Davidson 1990).

The use of scanning electron microscopy (SEM), offers great opportunity for the study of microstructural features of coal and coal products (Singh et al. 1987; Singh 1989; Singh and Singh 1990, 1995). Finkelman and Stanton (1978) suggest SEM as a brilliant tool for determining the maceral content and amounts of elements and minerals in the maceral. The scanning electron microscope can only deliver qualitative data. However, visual assessment of mineral matter and micro structural features may be carried out by evaluating the viewed surface area of the litho type shielded by mineral matter and by observing the number of places where the same micro structural features appear. Nowadays, computer-controlled advanced SEM is also available through which qualitative as well as quantitative 


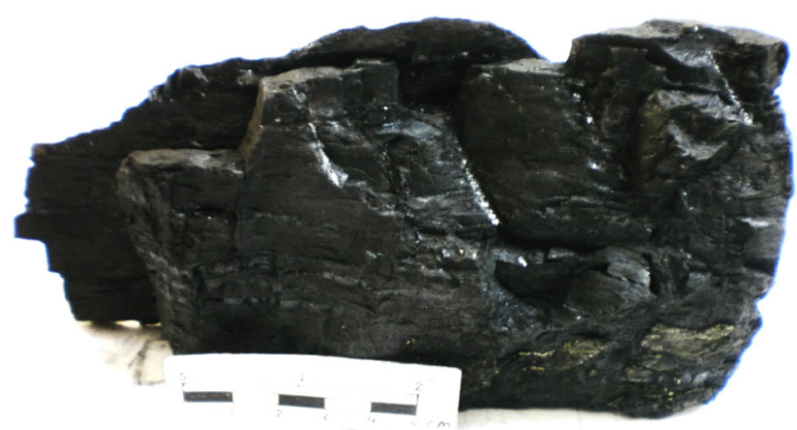

Fig. 1 A cross-section through a lump of coal showing vitrain, clarain, durain and fusain bands with mineral matter

mineral analysis is carried out and mineral matter-organic matter association, size distribution are also studied (Galbreath et al. 1996; Gupta et al. 1998; Creelman and Ward 1996; Gottlieb et al. 1991; Kalaitzidis and Christanis 2003; Liu et al. 2005; Saikia and Ninomiya 2011; Saikia et al. 2015; Singh et al. 2015a). To quantify the minerals present in the Ib and Umaria coal samples, X-ray powder diffraction (XRD) was carried out. XRD is the most extended tool to investigate the mineralogy of coal and their crystallisation phases and also to understand the exact nature of their structure and the progressive stages of coalification (Zhou et al. 2010; Mishra and Das 2010; Saikia et al. 2014; Singh et al. 2015b; Valentim et al. 2016; Mishra et al. 2016a, b).

The present paper entails an initial examination of the surface morphology of maceral and their relationship with the mineral matter in some coal samples collected from Ib river valley, Mahanadi basin, Odisha and Umaria coalfield, Madhya Pradesh. Some recent contributions on coal deposits of the Mahanadi valley have been made by Singh et al. 2013, Naik et al. 2016 and Mishra et al. 2016a. Nevertheless, the present study carried out under SEM and XRD would help in identifying their potential utilisation.

\section{Materials and methods}

Thirteen fresh Coal samples were collected from different collieries of Umaria and Ib-valley coalfield. The collected samples are from working face as full-seam channel samples from base to top in sub-seam intervals and were classified as per scheme given by Diessel (1965). The individual coal sample were crushed and pulverised for various analysis. The proximate analysis of the coal samples were carried out by standard methods (IS:1350 1984). The elemental analysis $(\mathrm{C}, \mathrm{H}, \mathrm{N}$, and $\mathrm{S})$ was conducted using Vario EL-III analyser.

To study the micro-constituents of coal (maceral), the coal samples were crushed to -18 mesh size. The moulds were prepared in cold medium using epoxy-resin and hardener and were subsequently polished for microscopic study. The maceral analysis was performed on a polarised incident-light microscope with an automatic photographic unit (Wild Photo-automat MPS 45) using established ICCP $(1963,1998,2001)$ recommendations.

The SEM study is performed on JEOL scanning electron microscope, model Philips 505. SEM samples were prepared by sprinkling powdered coal samples onto a carbon coated metallic holder followed by gold coating.

For X-ray diffraction (XRD) studies, representative coal samples powdered to 300 mesh size. XRD patterns were recorded on a Rigaku (D/Max III VC) instrument in the $2 \theta$ region of $2^{\circ}-60^{\circ}$. The obtained peaks in the diffractogram have been identified by the peak finding program. The 2-theta $(2 \theta)$ peaks were converted into corresponding $\mathrm{d}$-spacing and matched with the Joint Committee on Power Diffraction Standards (JCPDS) database.

\section{Results and discussion}

The proximate and ultimate analysis of coal samples were carried out in triplicate and mean values has been reported in Table 1. In general, all coal samples display high volatile matter (22.3\%-34.5 wt \% in Umaria coals and $24.0 \%-$ $34.0 \mathrm{wt} \%$ in $\mathrm{Ib}$ river coals on dry ash free basis) with a moderate ash yield (10.5-20.0 in Umaria coal and 16.0\%$24.2 \mathrm{wt} \%$ in $\mathrm{Ib}$ river coal on dry basis). In these coals, Umaria coals show low in liptinite content $(2.66 \%-4.35$ vol\% on mineral matter free basis) where as Ib valley coals contain moderate to high amount of liptinite $(3.15 \%-$ 9.85 vol\% on mineral matter free basis). The inertinite content, however, is high $(28.97 \%-65.76 \mathrm{vol} \%$ on mineral matter free basis) in these coals (Table 1).

Mineral matters occur in coal in different mode of occurrences. There are many different minerals that behave differently. The main minerals are quartz, metakaolinite, mullite, and rutile, while the common fluxing minerals are anhydrite, acid plagioclases, $\mathrm{K}$ feldspars, $\mathrm{Ca}$ silicates, and hematite (Creelman et al. 2013; Mishra et al. 2016a, b). Figure 2 represents XRD diffractogram of two samples (Umaria and $\mathrm{Ib}$ valley coal). It indicates clearly the presence of quartz $(\mathrm{Q})$, kaolinite $(\mathrm{K})$, siderite $(\mathrm{S})$ and hematite (H) as major mineral phases in both samples. The XRD patterns of both coals are found to show almost similar mineral composition. The identification of minor minerals only by XRD in a multi component system like coal is difficult due to the detection limits (normally at about $0.5 \%-1 \%$ ) and peak overlapping (Mishra et al. 2016a).

Figures 3 and 4, shows the SEM photographs of the various maceral of the Umaria and Ib valley coals.

Singh et al. (2015a) found a specific micro-structural relation between mineral matter and the coaly substance in 
Table 1 Chemical and petrographic characteristics of Umaria and IB-valley coal

\begin{tabular}{|c|c|c|c|c|c|c|c|c|c|c|}
\hline $\begin{array}{l}\text { Sample } \\
\text { No. }\end{array}$ & $\mathrm{M}$ & $\mathrm{VM}$ & A & $\mathrm{C}^{\mathrm{daf}}$ & $\mathrm{H}^{\mathrm{daf}}$ & $\mathrm{N}^{\mathrm{daf}}$ & $S^{\text {daf }}$ & Vitrinite $^{\mathrm{mmf}}$ & Liptinite $^{\mathrm{mmf}}$ & Inertinite $^{\mathrm{mm}}$ \\
\hline UC 1 & 6.5 & 30.5 & 17.8 & 80.9 & 5.5 & 1.00 & 0.51 & 53.55 & 4.35 & 42.10 \\
\hline UC 2 & 7.0 & 32.0 & 18.2 & 79.2 & 5.6 & 1.01 & 0.52 & 55.10 & 4.04 & 40.86 \\
\hline UC 3 & 4.7 & 22.3 & 20.0 & 84.7 & 5.1 & 1.04 & 0.61 & 41.54 & 2.66 & 55.80 \\
\hline $\mathrm{UC} 4$ & 6.3 & 34.5 & 10.5 & 81.4 & 5.6 & 1.06 & 0.54 & 56.32 & 4.23 & 39.45 \\
\hline IC 1 & 5.3 & 31.3 & 21.0 & 80.7 & 5.7 & 0.79 & 0.50 & 58.83 & 5.80 & 35.37 \\
\hline IC 2 & 6.0 & 29.7 & 16.0 & 81.6 & 5.5 & 0.77 & 0.54 & 65.80 & 5.23 & 28.97 \\
\hline IC 3 & 6.0 & 27.7 & 24.2 & 80.8 & 5.5 & 0.79 & 0.72 & 49.60 & 7.45 & 42.95 \\
\hline IC 4 & 5.0 & 34.0 & 18.5 & 80.5 & 5.8 & 0.75 & 0.79 & 33.25 & 9.85 & 56.90 \\
\hline IC 5 & 5.5 & 26.0 & 24.0 & 81.8 & 5.4 & 0.87 & 0.97 & 57.25 & 3.15 & 39.60 \\
\hline IC 6 & 5.7 & 27.6 & 21.7 & 81.6 & 5.5 & 0.74 & 0.91 & 31.81 & 9.32 & 58.87 \\
\hline IC 7 & 6.0 & 24.0 & 21.0 & 82.9 & 5.2 & 0.72 & 0.81 & 33.05 & 6.95 & 60.00 \\
\hline IC 8 & 5.6 & 30.7 & 17.3 & 81.5 & 5.6 & 0.74 & 0.83 & 28.61 & 5.63 & 65.76 \\
\hline IC 9 & 4.7 & 29.5 & 17.2 & 82.4 & 5.4 & 0.74 & 0.68 & 36.60 & 8.40 & 55.00 \\
\hline
\end{tabular}

$M$ moisture, $V M$ volatile matter (wt \%), $A$ ash yield (wt $\%$ ), $C$ carbon (wt $\%), H$ hydrogen (wt $\%), N$ nitrogen (wt $\%$ ), $S$ sulphur (wt $\%$ ), daf dry ash free basis, $m m f$ mineral matter free basis
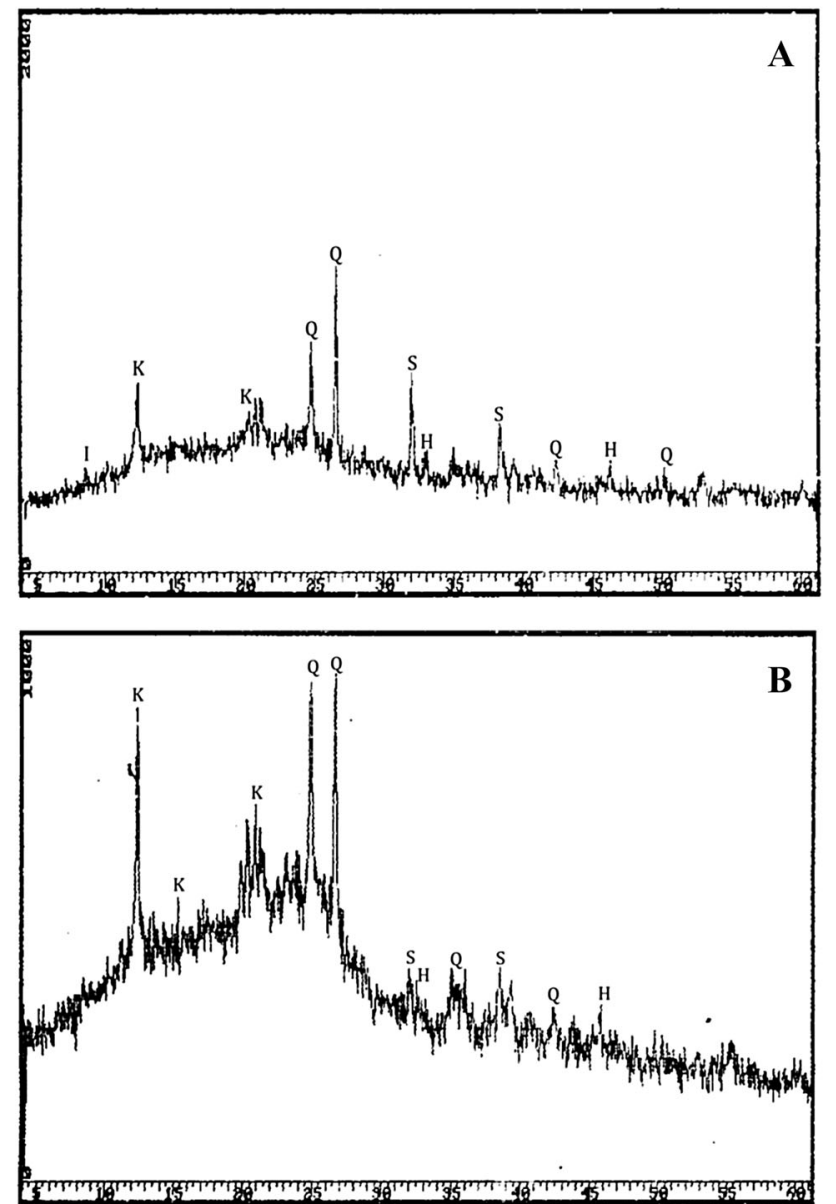

Fig. 2 XRD diffractograms of coal samples. a Ib-valley coal, b Umaria coal. $H$ hematite, $I$ illite, $K$ kaolinite, $Q$ quartz, $S$ siderite
Meghalaya coal. In the moderately dull coal, mineral matter occurs as superficial impregnation and cavity filling; in moderately bright coal as superficial impregnation, cavity filling, and intimate intergrowth; and in bright coals as superficial mounting and pore fillings. In Umaria and Ib valley coal, in general mineral matter is more dominant in dull bands as compared to the brighter ones (Fig. 3d-f). The micro structural relationships between coaly substances and mineral matter in vitrain, appears as amorphous mass with conchoidal fracture or observed mainly superficial mounting (Fig. 3a), superficial blanketing (Fig. 3b, c), deep intergrowth (Fig. 3d) and massive impregnation (Fig. 3c). Saikia (2009) has reported two different morphological types of collotelinite in Assam coals. Those are of typically angular in shape and with parallel laminations. Increase in coal rank appears to increase the number of laminations and give more ordered system of stacked sheets. Particular, in Umaria coal, telinite shows cellular structures with woody matter compressed probably due to pressure (Fig. 3e, f). In case of clarain, characterised by alternate thin bands of vitrain and durain, mineral matter occurs as superficial blanketing and cellular cavity filling. In dull bands it occurs as massive intergrowth and deep impregnations. In durain which is characterised by structureless, compact, residual ground mass, the mineral matter occurs as intergrowth and massive impregnation. This lithotype records the maximum contamination. Finkelman and Stanton (1978) found pyrite concentrated in vitrinite macerals; illite, quartz, and rutile in the carbominerite; and kaolinite in fusinite and semifusinite. Finkelman (1980) has reported sulfides, concentrated in inertinites and vitrinites. 

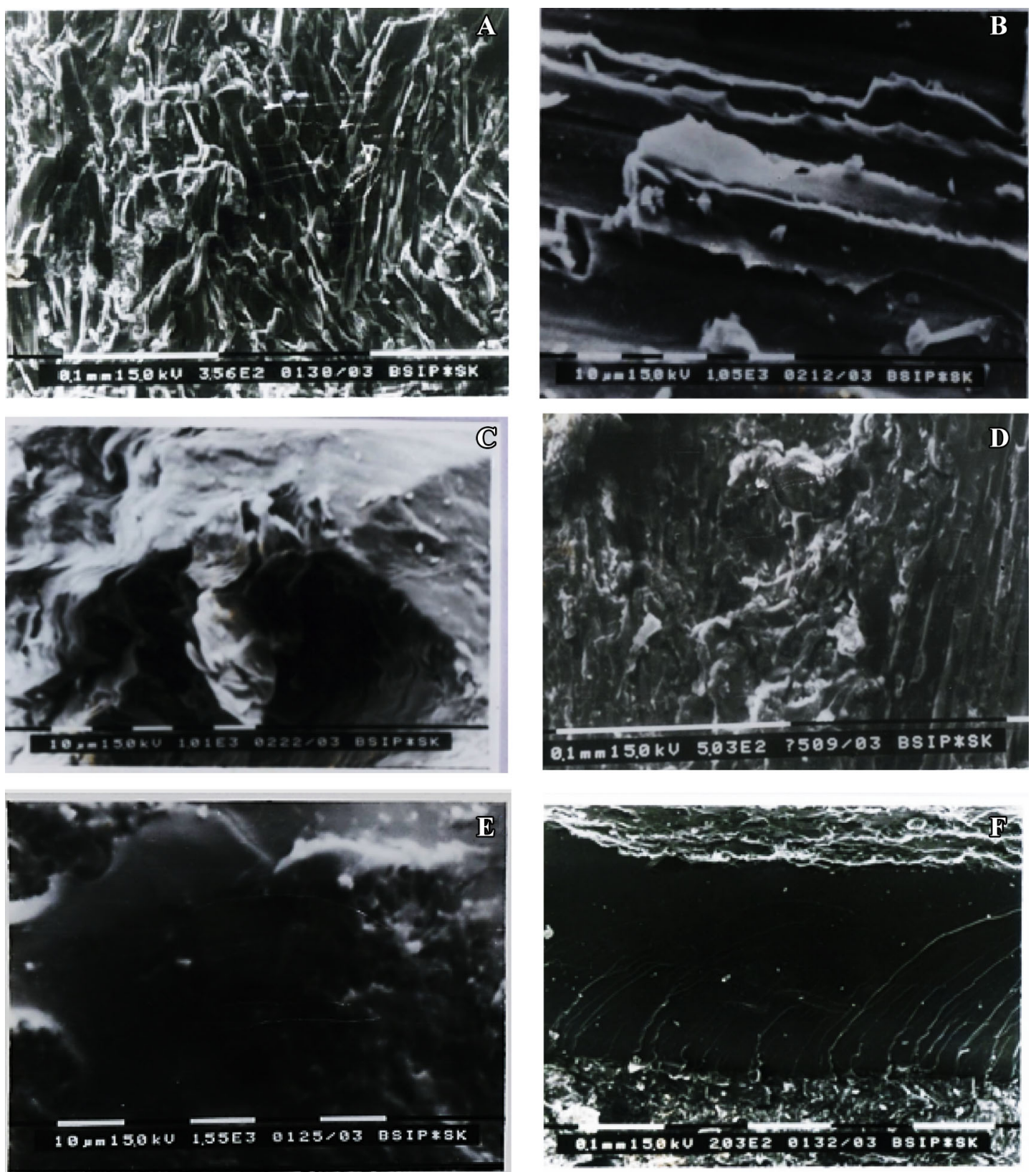

Fig. 3 SEM photomicrographs a-d showing vitrain band from Umaria and Ib valley with superficial mounting, mineral impregnation, cavity filling and mineral matter filling in tracheids. SEM photomicrographs $\mathbf{e}, \mathbf{f}$ showing clarain band from the same coalfield with mineral intergrowth, deep impregnation and superficial mounting of mineral matter dominantly of argillaceous siliceous and sideritic composition

Late epigenetic minerals, such as kaolinite, siderite, pyrite, calcite, barite and silica and most commonly the aluminum silicates have been reported by Finkelman (1980) to occur in micro cleats of coal. In the present investigation, the voids are seen to be filled with clayey, sideritic and at places limonitic mineral matter (Fig. 4a, b). Davis et al. (1986) and Saikia (2009) have reported rod-like (needle) cylinders resembling fossilised xylem plant vessels in coal. In case of Ib valley and Umaria coal, generally the concentration of mineral matter is less in fusain. The mineral matter has been found in pitted vessels of parenchyma. The pitted vessels and mechanical cavities owe their origin to the crushing of cell fibres (Fig. 4c-f).

\section{Conclusions}

Most of the minerals in the coals of the study area are superficially mounted. Mineral impregnation in cell wall is flocculated with granulated texture. At some places these show relict structures. In cracks and fissures, sideritic mineral matter forms hard ridges and relict structure. Some 

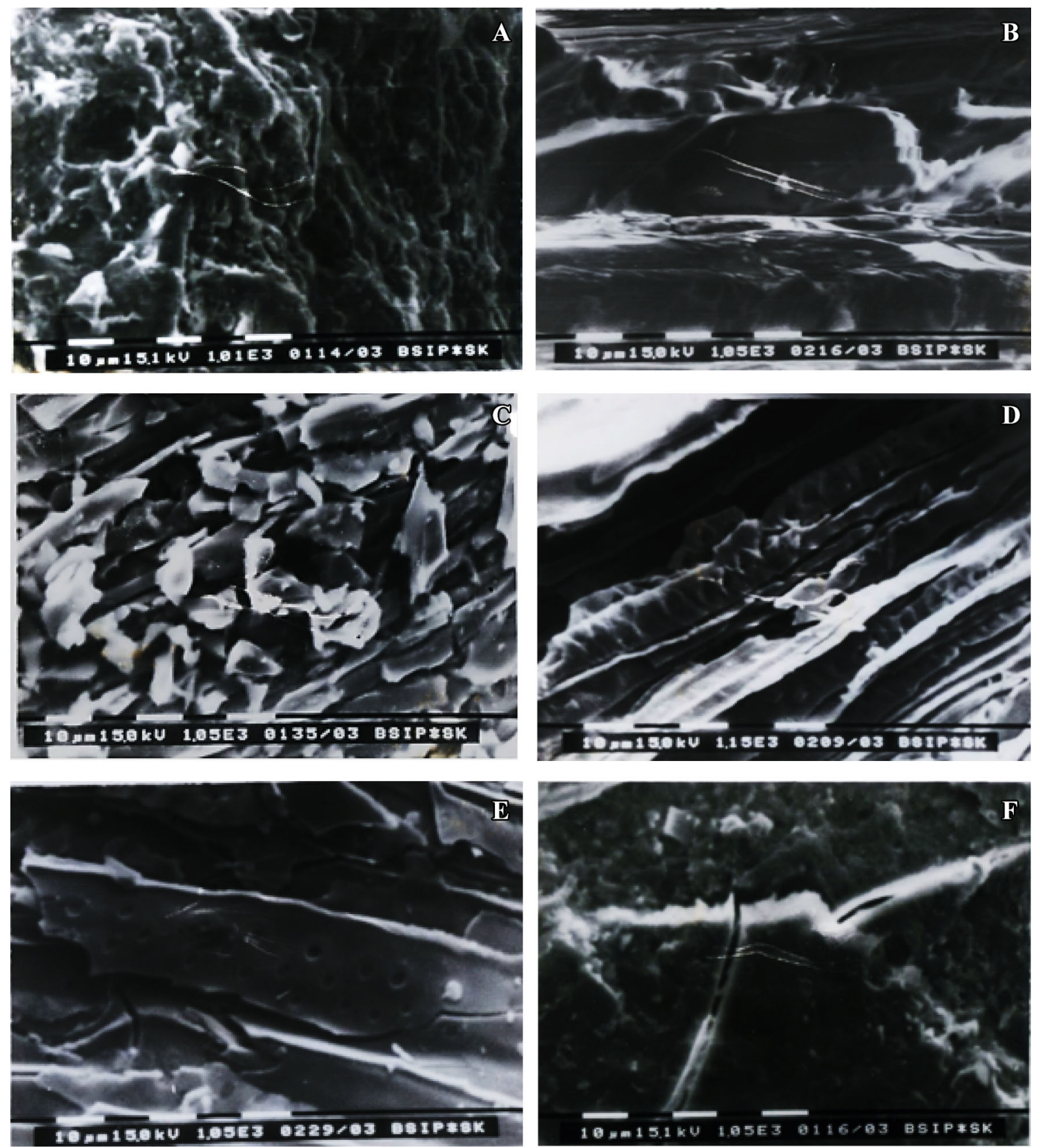

Fig. 4 SEM photomicrographs a, b showing durain band from Umaria and Ib valley respectively with maximum coating of mineral matter including voids filling with clayey and sideritic mineral matter. SEM photomicrographs $\mathbf{c}-\mathbf{f}$ show fusain band from the same coalfield having minimum interaction with mineral matter. Some crushed cells/vessels are also seen with sporadic mineral inclusion in veins

pits have been distinguished in fusains. These pits are the parts of tracheid and mostly free from any mineral matter specially in Ib valley coals.

The present investigation reveals that durain contains maximum mineral matter contamination while fusain has been minimum. Due to high mineral matter durain appears dull under SEM. In decreasing sequence of mineral matter the lithotype can be arranged as durain $>$ clarain $>$ vitrain $>$ fusain.
Acknowledgements Authors are grateful to Director, Birbal Sahni Institute of Palaeobotany, Lucknow for providing laboratory facilities. Thanks are also due to the lab facilities given by S.I.F. centre, C.D.R.I. Lucknow. Authors gratefully acknowledge the University Grants Commission, New Delhi, India's for financial support to this project.

Open Access This article is distributed under the terms of the Creative Commons Attribution 4.0 International License (http://crea tivecommons.org/licenses/by/4.0/), which permits unrestricted use, distribution, and reproduction in any medium, provided you give appropriate credit to the original author(s) and the source, provide a 
link to the Creative Commons license, and indicate if changes were made.

\section{References}

Creelman RA, Ward CR (1996) A scanning electron microscope method for automated quantitative analysis of mineral matter in coal. Int J Coal Geol 30:249-269

Creelman RA, Ward CR, Schumacher G, Juniper L (2013) Relation between coal mineral matter and deposit mineralogy in pulverized fuel furnaces. Energy Fuels 27:5714-5724

Davidson R (1990) Elements and minerals in coal macerals. Energy Sources 12(1):33-55

Davis MR, White A, Deegan MD (1986) Scanning electron microscopy of coalmacerals. Fuel 65:277-280

Diessel C (1965) Correlation of macro- and micropetrography of some New South Wales coals. In: 243 proceedings 8th commonwealth mining and metallurgical congress, vol 6 , pp 669-677

Finkelman RB (1980) Modes of occurrence of trace elements in coal. Ph.D. diss., University of Maryland

Finkelman RB, Stanton RW (1978) Identification and significance of accessory minerals from a bituminous coal. Fuel 57:763-768

Galbreath K, Zygarlicke C, Casuccio G, Moore T, Gottilieb P, AgronOlshina N, Huffman G, Shah A, Yang N, Vleeskena J, Hamburg G (1996) Collaborative study of quantitative coal mineral analysis using computer-controlled scanning electron microscopy. Fuel 15:424-430

Gottlieb P, Agron-Olshina N, Sutherland DN (1991) The characterization of mineral matter in coal and fly ash. In: Proceedings of the engineering foundation conference on inorganic transformation and ash deposition during combustion, Florida, March $10-15$, pp 135-146

Gupta RP, Wall TF, Kajigaya I, Miyamae S, Tsumita Y (1998) Computer-controlled scanning electron microscopy of minerals in coal-implication for ash deposition. Prog Energy Combust Sci 24:523-543

ICCP (1963) International handbook of coal petrography, 2nd edn. Centre National de la RecherchéScientifique, Academy of Sciences of the URSS, Paris

ICCP (1998) The new vitrinite classification. International Committee for Coal and Organic and Petrology (ICCP System 1994). Fuel 77:349-358

ICCP (2001) The new inertinite classification. International Committee for Organic and Coal Petrology, (ICCP System 1994). Fuel 80:459-471

Indian Standard (IS:1350) Part-1 (1984) Methods of test for coal and coke: proximate analysis (Part 1). Bureau of Indian Standard, New Delhi, pp 1-29

Kalaitzidis S, Christanis K (2003) Scanning electron microscope studies of the Philippi peat (NE Greece): initial aspects. Int J Coal Geol 54:69-77

Kroeger C (1964) On the structure and constitution of coal. In: Erdoel und Kohle-Erdgas-Petrochemie. Industrial publishers von Hernhaussen Co, Hamburg, pp 802-811

Liu Y, Gupta R, Sharma A, Wall T, Butcher A, Miller G, Gottlieb P, French D (2005) Mineral matter-organicmatter association characterization by QEMSCAN and applications in coal utilization. Fuel 84:1259-1267

Mishra DP, Das SK (2010) A study of physico-chemical and mineralogical properties of Talcher coal fly ash for stowing in underground coal mines. Mater Charact 61:1252-1259
Mishra V, Bhowmick T, Chakravarty S, Varma AK, Sharma M (2016a) Influence of coal quality on combustion behaviour and mineral phases transformations. Fuel 186:443-455

Mishra V, Sharma M, Chakravarty S, Banerjee A (2016b) Changes in organic structure and mineral phases transformation of coal during heat treatment on laboratory scale. Int J Coal Sci Technol $3: 418-428$

Moore TA, Ferm JC (1992) Composition and grain-size of an Eocene coal bed in southeastern Kalimantan, Indonesia. Int J Coal Geol 21:1-30

Naik AS, Singh MP, Volkmann N, Singh PK, Mohanty D, Kumar D (2016) Petrographic characteristics and paleomires of MandRaigarh coals, Mahanadi Gondwana Basin, Chhattisgarh, India. Int J Coal Sci Technol 3(2):165-183

Pierce BS, Stanton RW, Eble CF (1991) Facies development in the lower Freeport coal bed, west-central Pennsylvania, U.S.A. Int J Coal Geol 18:17-43

Saikia BK (2009) Scanning Electron Microscopy of Assam Coals, India. J Geol Soc India 74:749-752

Saikia BK, Ninomiya Y (2011) An investigation on the heterogeneous nature of mineral matters in Assam (India) coal by CCSEM technique. Fuel Process Technol 92(5):1068-1077

Saikia BK, Ward CR, Oliveira MLS, Hower JC, Baruah BP, Braga M, Silva LF (2014) Geochemistry and nano-mineralogy of two medium-sulfur northeast Indian coals. Int J Coal Geol 121:26-34

Saikia BK, Das T, Baruah BP (2015) Size distribution of particles in high sulphur coal ash and their chemistry: a computer-controlled scanning electron microscopic study. J Geol Soc India $85: 206-214$

Seyler CA (1928) On the Dictyoxylon cortex of lycopodiales as a constituent of coal. Philos Trans R Soc Lond 216:353-362

Shearer JC (1992) Sedimentology, coal chemistry and petrography of the Morley and Beaumont coal measures, Ohai coalfield, New Zealand. University of Canterbury, Ph.D., Christchurch, New Zealand

Shirazi AR, Eklund L, Lindqvist O (1994) Direct quantitative analysis of mineral matter and different forms of pyritic sulfur in coal by electron probe microanalysis (EPMA) and automated image analysis (AIA). Fuel 73:193-198

Singh MP (1989) On the origin of fusain of the tertiary coals of Meghalaya. J Geol Soc India 33(4):99-103

Singh MP, Singh GP (1990) Occurrence and distribution of mineral matter in Jammu coals: emanations of scanning electron micrography. J Geol Soc India 62(4):249-256

Singh MP, Singh PK (1995) Mineral matter in Rajmahal coal: study through incident light microscopy and scanning electron micrography. J Geol Soc India 46:557-564

Singh MP, Singh RM, Chandra D (1987) Scanning electron microscopic studies of mineral matter in Ghugus coals, Wardha vally coalfields, district Chandrapur and Yeotmal, Maharastra. J Geol Soc India 59(1):56-64

Singh PK, Singh GP, Singh MP, Naik AS (2013) Petrology of coals from rampur seam-IV and Lajkura seam, Ib River coalfield, Mahanadi valley, Orissa, India. Energy Sour Part A Recover Util Environ Eff 35:1681-1690

Singh AK, Singh MP, Singh PK (2015a) Microstructural relation of macerals with mineral matter in Eocene coal. Energy Sour Part A: Recovery Util Environ Eff 37(10):1089-1097

Singh AL, Singh PK, Kumar A, Singh MP (2015b) Demineralization of Rajmahal Gondwana coals by bacteria: revelations from X-ray diffraction (XRD) and Fourier transform infra-red (FTIR) studies. Energy Explor Exploit 33(5):755-767

Stanton RW, Moore TA (1991) The necessity for etching. Soc Organic Petrol Newsl Lab Notes 8(1):8-11 
Thomas KM (1986) Coal structure. Carbon and coal gasification. Martinus Nijhoff Publishers, Dordrecht, pp 57-92

Valentim B, Flores D, Guedes A, Guimarães R, Shreya N, Paul B, Ward CR (2016) Notes on the occurrence of phosphate mineral relics and spheres (phosphospheres) in coal and biomass fly ash. Int J Coal Geol 154-155:43-56

Winston RB (1988) Paleoecology of Middle Pennsylvanian-age peatswamp plants in Herrin coal, Kentucky, U.S.A. Int J Coal Geol 10:203-238
Winston RB (1989) Identification of plant megafossils in Pennsylvanian-age coal. Rev Palaeobot Palynol 57:265-276

Xie KC (2015) Structure and reactivity of coal. Springer, Heidelberg, pp $1-5$

Zhou J, Zhuang X, Alastuey A, Querol X, Li J (2010) Geochemistry and mineralogy of coal in the recently explored Zhundong large coal field in the Junggar basin, Xinjiang Province, China. Int $\mathrm{J}$ Coal Geol 82:51-67 